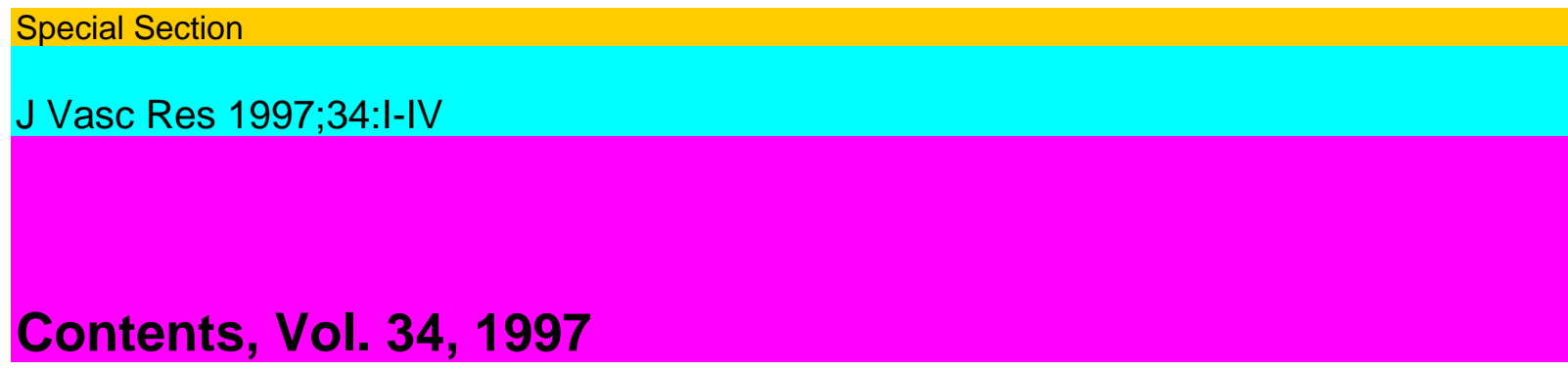

Main Editor

M.J. Mulvany, Aarhus

Co-Editor

G.K. Owens, Charlottesville, Va.

Associate Editors

H. Haller, Berlin

D.R. Harder, Milwaukee, Wise.

Editorial Assistants

J. Clatterbuck, Charlottesville, Va. L. Svendsen, Aarhus

Editorial Board

C. Aalkjær, Aarhus

K.E. Andersson, Lund

J.A. Angus, Prahran

J.A. Bevan, Burlington, Vt.

H.G. Bohlen, Indianapolis, Ind.

G. Burnstock, London

R. Busse, Frankfurt/Main

J. Campbell, Brisbane

P.A. D'Amore, Boston, Mass.

E.E. Daniel, Hamilton

P.F. Davies, Philadelphia, Pa.

P. DiCorleto, Cleveland, Ohio

B.R. Duling, Charlottesville, Va.

J.E. Faber, Chapel Hill, N.C.

R.F. Furchgott, Brooklyn, N.Y.

G. Gabella, London

M.A. Gimbrone, Boston, Mass.

R.J. Gryglewski, Cracow

C.-H. Heldin, Uppsala

P. Hellstrand, Lund

K. Hermsmeyer, Portland

O. Hudlicka, Birmingham

A.D. Hughes, London

W.F. Jackson, Kalamazoo, Mich.

R.A. Johns, Charlottesville, Va. 


\section{B.L. Langille, Toronto}

J. Linden, Charlottesville, Va.

S.E. Luff, Prahran

T. Maciag, Rockville, Md.

M. Majesky, Houston, Tex.

J.C. McGrath, Glasgow

V. Miller, Rochester, Minn.

R.S. Moreland, Philadelphia, Pa.

O.A. Nedergaard, Odense

M.T. Nelson, Burlington, Vt.

E. Olson, Houston, Tex.

G. Osol, Burlington, Vt.

R.J. Paul, Cincinnati, Ohio

R. Prewitt, Norfolk, Va.

E.M. Renkin, Davis, Calif.

W. Risau, Bad Nauheim

G.M. Rubanyi, Richmond, Calif.

H. Sage, Seattle, Wash.

S. Sartore, Padova

G.W. Schmid-Schönbein,

La Jolla, Calif. S.M. Schwartz, Seattle, Wash. W.C. Sessa, New Haven, Conn. H. Singer,

Danville, Pa. A.P. Somlyo, Charlottesville, Va. H.A.J. Struijker-Boudier, Maastricht N. Toda, Ohtsu

C. VanBreemen, Miami, Fla.

D. Webb, Edinburgh

\section{KÄRGER}

Basel $\cdot$ Freiburg $\cdot$ Paris $\cdot$ London $\cdot$ New York $\cdot$ New Delhi $\cdot$ Bangkok $\cdot$ Singapore $\cdot$ Tokyo $\cdot$

\section{Sydney}

\section{KARGER}

\section{S. Karger}

Medical and Scientific Publishers Basel · Freiburg · Paris · London New York · New Delhi · Bangkok Singapore $\cdot$ Tokyo $\cdot$ Sydney

Drug Dosage

The authors and the publisher have exerted every effort to ensure that drug selection and dosage set forth in this text are in accord with current recommendations and practice at the time of publication. However, in view of ongoing research, changes in government regulations, and the constant flow of information relating to drug therapy and drug reactions, the reader is urged to check the package insert for each drug for any change in indications and dosage and for added warnings and precautions. This is particularly important when the recommended agent is a new and/or infrequently employed drug.

All rights reserved.

No part of this publication may be translated into other languages, reproduced or utilized in any form or by any means, electronic or mechanical, including photocopying, recording, microcopying, or by any information storage and retrieval system, without permission in writing 
from the publisher or, in the case of photocopying, direct payment of a specified fee to the Copyright Clearance Center (see 'General Information').

(C) Copyright 1997 by S. Karger AG, P.O. Box, CH-4009 Basel (Switzerland) Printed in

Switzerland on acid-free paper by Reinhardt Druck, Basel

Contents Vol. 34, 1997

Journalo,\%oscuIar Research

No. 1

Research Papers

1

Tyrosine Phosphorylation and Regulation of Swine Carotid Artery Contraction

Rembold, CM.; Weaver, B.A. (Charlottesville, Va.)

11 Pituitary Adenylate-Cyclase-Activating Peptides Relax Human Coronary Arteries by

Activating KATP and KCa Channels in Smooth Muscle Cells

Bruch, L.; Bychkov, R.; Kästner, A.; Bülow, T.; Ried, C; Gollasch, M.; Baumann, G.; Luft, F.C.;

Haller, H. (Berlin)

19 Connexin43 Gene Expression in the Rabbit Arterial Wall: Effects of Hypercholesterolemia,

Balloon Injury and Their Combination

Polacek, D.; Bech, F.; McKinsey, J.F.; Davies, P.F. (Chicago, Ill.)

31 Neurocompensatory Responses to Balloon-Catheter-Induced Injury of the Rat Carotid Artery

Milner, P.; Crowe, R.; Loesch, A.; Anglin, S.; Burnstock, G.; McEwan, J.R. (London)

$41 \alpha$-Thrombin Induces Transforming Growth Factor- $\beta$, mRNA and Protein in Cultured Vascular

Smooth Muscle Cells via a Proteolytically Activated Receptor

Bachhuber, B.G.; Sarembock, I.J.; Gimple, L.W.; Owens, G.K. (Charlottesville, Va.)

49 Vasodilatory Effects of a Salen-Manganese Complex with Potent Oxyradical Scavenger

Activities

Barandier, C; Boucher, F. (Grenoble); Malfroy, B. (Bedford, Mass.); de Leiris, J. (Grenoble)

58 Monocyte Chemotactic Protein 1 (MCP-1) Is a Mitogen for Cultured Rat Vascular Smooth

Muscle Cells

Porreca, E.; Di Febbo, C; Reale, M.; Castellani, M.L.; Baccante, G; Barbacane, R.; Conti, P.;

Cuccurullo, F.; Poggi, A. (Chieti)

66 Conference Calendar

No. 2

117 Effect of Pressurization on Mechanical Properties of

Mesenteric Small Arteries from Spontaneously Hypertensive Rats

Laurant, P. (Besançon); Touyz, R.M.; Schiffrin, E.L. (Montreal)

126 Aortic Elastin and Collagen Content and Synthesis in Two

Strains of Rats with Different Susceptibilities to Rupture of the Internal Elastic Lamina

Sauvage, M.; Jacob, M.-P.; Osborne-Pellegrin, M. (Paris)

137 Age-Related Differences in Elastic Properties of the Upper Arm Vascular Bed in Healthy

Adults

Muntinga, J.H.J.; Schut, J.K.; Visser, K.R.; Zijlstra, W.G. (Groningen)

148 Conference Calendar

No. 3

Introduction

149 A Symposium on Signal Transduction in the Endothelium

Vancouver, September 9-11,1996 
van Breemen, C; Wang, X. (Vancouver)

152 Signal Transduction Mechanisms Mediating the Vascular Actions of Endothelin

Douglas, S.A.; Ohlstein, E.H. (King of Prussia, Pa.)

165 Calcium-Dependent and Calcium-Independent Activation of the Endothelial NO Synthase

Fleming, I.; Bauersachs, J.; Busse, R. (Frankfurt/Main)

$175 \mathrm{G}$ Proteins and Endothelium-Dependent Relaxations

Boulanger, CM. (Paris); Vanhoutte, P.M. (Courbevoie) 186 Calcium-Release-Activated Calcium Influx in Endothelium

Davis, M.J.; Sharma, N.R. (College Station, Tex.)

196 Multiple Mechanisms of Activating Ca2+ Entry in Freshly Isolated Rabbit Aortic

Endothelial Cells

Wang, X.; van Breemen, C. (Vancouver)

Commentary

Review

67 Resistance and Conduit Arteries following Converting Enzyme Inhibition in Hypertension

Safar, M.E. (Paris); van Bortel, L.M.A.B.; Struijker-Boudier, H.A.J. (Maastricht)

Research Papers

82 G Proteins and Phospholipase C Mediate Thrombin-lnduced Generation of Plasminogen

Activator Inhibitor-1 from Vascular Smooth Muscle Cells

Ren, S.; Cockell, K.A. (Winnipeg); Fenton II, J.W. (Albany, N.Y.); Angel, A.; Shen, GX.

(Winnipeg)

90 Adrenoceptor-Mediated Regulation of the Contractility in Horse Penile Resistance Arteries

Simonsen, U.; Prieto, D.; Hernandez, M. (Madrid); Saenz de Tejada, I. (Boston, Mass.); GarcíaSacristán, A. (Madrid)

103 Inhibition of Calcium Entry Preserves Contractility of Arterial Smooth Muscle in Culture Lindqvist, A.; Nilsson, B.-O.; Hellstrand, P. (Lund) 109 Myogenic Tone in Coronary Arteries from Spontaneously Hypertensive Rats

Garcia, S.R.; Izzard, A.S.; Heagerty, A.M.; Bund, S.J. (Manchester)

208 Overview: Temporal and Spatial Relationships in Shear Stress-Mediated Endothelial

Signalling

Davies, P.F. (Philadelphia, Pa.)

212 Mechanotransduction in Endothelial Cells: Temporal Signaling Events in Response to Shear Stress

Takahashi, M,; Ishida, T.; Traub, O.; Corson, M.A.; Berk, B.C. (Seattle, Wash.)

220 Multiple Types of Chloride Channels in Bovine Pulmonary Artery Endothelial Cells

Nilius, B.; Szücs, G; Heinke, S,; Voets, T.; Droogmans, G. (Leuven)

229 Potential Cellular Signaling Mechanisms Mediating Upregulation of Endothelial Nitric

Oxide Production by Estrogen

Kauser, K.; Rubanyi, G.M. (Richmond, Calif.)

237 Cytochrome P450 Metabolites of Arachidonic Acid as Intracellular Signaling Molecules in Vascular Tissue

Harder, D.R.; Lange, A.R.; Gebremedhin, D,; Birks, E.K.; Roman, R.J. (Milwaukee, Wise.)

244 Conference Calendar 243 Errata

\section{KAIVGEK}


Fax+41 613061234 E-Mail karger@,karger.ch www.karger.com

(C) 1997S. KargerAG, Basel

The list of contents is available at: www.karger.com/journals/jvr/jvrcont.htm

III

No. 4

Research Papers

245 Cyclic GMP-Dependent Protein Kinase Regulates Vascular Smooth Muscle Cell Phenotype Boerth, N.J.; Dey, N.B.; Cornwell, T.L.; Lincoln, T.M. (Birmingham, Ala.)

260 The Influence of Lesion Length on Intimal Hyperplasia after Fogarty Balloon Injury in the Rabbit Carotid Artery: Role of Endothelium

Doornekamp, F.N.G.; Borst, C. (Utrecht); Post, M.J. (Utrecht/Boston, Mass.)

267 Vascular Effects of Proteinase-Activated Receptor 2 Agonist Peptide

Emilsson, K. (Lund); Wahlestedt, C. (Laval); Sun, M.-k. (New York, N.Y.); Nystedt, S.;

Owman, C; Sundelin, J. (Lund)

273 Regulation of the Fibrinolytic Potential of Cultured Human Umbilical Vein Endothelial

Cells: Astragaloside IV Downregulates Plasminogen Activator Inhibitor-1 and Upregulates

Tissue-Type Plasminogen Activator Expression

Zhang, W.-J. (Vienna/Beijing); Wojta, J.; Binder, B.R. (Vienna)

281 Estrogen Does Not Induce the Calcium-Dependent Nitric Oxide Synthase in Cultured

Human Uterine Endothelial and Myometrial Smooth Muscle Cells

Tschugguel, W.; Zhegu, Z.; Schneeberger, C; Tantscher, E.; Czerwenka, K.; Fabry, A.; Wojta, J.; Zeillinger, R.; Huber, J.C. (Vienna)

289 Angiotensin II Induces Media Hypertrophy and Hyperreactivity in Mesenteric but Not

Epigastric Small Arteries of the Rat

Stassen, F.R.M.; Raat, N.J.H.; Brouwers-Ceiler, D.L.; Fazzi, G.E.; Smits, J.F.M.; De Mey,

J.G.R. (Maastricht)

298 The Wall to Lumen Ratio of the Radial Artery in Patients with Raynaud's Phenomenon

Mourad, J.-J.; Priollet, P.; Girerd, X.; Safar, M.; Lazareth, L; Laurent, S. (Paris)

306 Combined Physical Therapy for Lymphedema Evaluated by Fluorescence

Microlymphography and Lymph Capillary Pressure Measurements

Franzeck, U.K.; Spiegel, I.; Fischer, M.; Börtzler, C. (Zurich); Stahel, H.-U. (Zurich-

Stadelhofen); Bollinger, A. (Zurich)

312 Influence of Hypoxia/lschemia on Cerebrovascular Responses to Oxytocin in Piglets

Bari, F. (Winston-Salem, N.C./Szeged); Errico, R.A. (Winston-Salem, N.C.); Louis, T.M.

(Greenville, N.C.); Busija, D.W. (Winston-Salem, N.C.)

Letters to the Editor

321

Is the Phenotypic Change in Vascular Smooth Muscle Cells a Prerequisite for the Efficacy of Environmental Cues as Inducers of Arterial Wall Lesions?

322

Bobik, A. (Melbourne) Reply

Sartore, S. (Padua)

324 Conference Calendar

365 Subendothelial Proteoglycan Synthesis and Transforming Growth Factor Beta Distribution

Correlate with Susceptibility to Atherosclerosis

Scott, L,; Kerr, A.; Haydock, D,; Merrilees, M. (Auckland) 
Induction of Smooth Muscle Cell Nitric Oxide Synthase by Human Leukaemia Inhibitory Factor: Effects in vitro and in vivo

Moran, C.S.; Campbell, J.H.; Campbell, GR. (Brisbane)

386

Aortic Calcification Produced by Vitamin D3 plus Nicotine

Niederhoffer, N. (Nancy); Bobryshev, Y.V. (Darlinghurst); Lartaud-Idjouadiene, I.; Giummelly, P.; Atkinson, J. (Nancy)

399

Cold Storage Induces an Endothelium-Independent Relaxation to Hypoxia/Reoxygenation in Porcine Coronary Arteries

Shimizu, S.; Shimizu, K.; Paul, R.J. (Cincinnati, Ohio)

408 Conference Calendar

No. 6

Review

409 Platelet Adhesion and Aggregation without Endothelial Denudation or Exposure of Basal Lamina and/or Collagen

Rosenblum, W.I. (Richmond, Va.)

Research Papers

418 Endothelin-1-lnduced Constriction Inhibits Nitric-Oxide-Mediated Dilation in Isolated Rat Resistance Arteries

Bakker, E.N.T.P.; van der Linden, P.J.W.; Sipkema, P. (Amsterdam)

425 Flow-Mediated Regulation of Endothelin Receptors in

Cocultured Vascular Smooth Muscle Cells: An Endothelium-Dependent Effect

Redmond, E.M.; Cahill, P.A.; Sitzmann, J.V. (Washington, D.C.)

436 Local Application of Angiotensin II to the Rat Carotid Artery Induces Adventitial

Thickening

Scheidegger, K.J.; Wood, J.M. (Basel)

447 Endothelin Does Not Contribute to the Attenuation in

Myocardial Function and Blood Flow after Repetitive Ischemia in the Rat Heart

Tiefenbacher, C.P. (Heidelberg); Tweddell, A. (Glasgow); Batkai, S.; Zimmermann, R.;

Tillmanns, H.; Kübler, W. (Heidelberg)

455 New Model for the Study of Angiogenesis and Antiangiogenesis in the Chick Embryo

Chorioallantoic Membrane: The Gelatin Sponge/Chorioallantoic Membrane Assay

Ribatti, D. (Bari); Gualandris, A.; Bastaki, M. (Brescia); Vacca, A.; Iurlaro, M.; Roncali, L.

(Bari); Presta, M. (Brescia)

464 Receptor Subtypes Involved in Relaxation and Contraction by Arginine Vasopressin in Canine Isolated Short Posterior Ciliary Arteries

Okamura, T.; Toda, M.; Ayajiki, K.; Toda, N. (Seta)

No. 5

Review

Conference Calendar

Thanks to the Reviewers 
Author Index Vol. 34,1997

Subject Index Vol. 34,1997

325 Sarcoplasmic Reticulum-Sarcolemma Interactions and Vascular Smooth Muscle Tone Laporte, R. (Boston, Mass.); Laher, I. (Vancouver)

Research Papers

344

Lack of Bradykinin-Induced Smooth Muscle Cell Hyperpolarization despite Heterocellular Dye Coupling and Endothelial Cell Hyperpolarization in Porcine Ciliary Artery

Bény, J.-L. (Geneva); Zhu, P.; Haef1/8er, I.O. (Basel)

351

Projections of Sympathetic Non-Noradrenergic Neurons to Skeletal Muscle Arteries in GuineaPig Limbs Vary with the Metabolic Character of Muscles

Grasby, D.J.; Gibbins, I.L.; Morris, J.L. (Adelaide)

Suppl. 1

7th Symposium on Mechanisms of Vasodilatation July 6-9, 1997, Maastricht, The Netherlands Abstracts

Organizing Committee: Vanhoutte, P.M. (Courbevoie); Boulanger, CM. (Paris); De Mey, J.G.R. (Maastricht); Flavahan, N.A. (Baltimore, Md.); Reneman, R.S.; Struijker Boudier, H.A.J.

(Maastricht)

IV JVase Res Vol. 34, 1997

Contents 